\title{
Production and nutritional quality of ryegrass forage grown in different population stands under successive cuts
}

\section{Produção e qualidade nutricional da forragem do azevém cultivado em diferentes estandes populacionais sob regime de cortes sucessivos}

\author{
André Dochwat ${ }^{1}$; Mikael Neumann ${ }^{2}$; Edelmir Silvio Stadler Junior ${ }^{3}$; \\ Bruno José Venancio ${ }^{3}$; Emylli Pereira e Silva ${ }^{4}$; Giovanna Bobato Pontarolo ${ }^{5}$; \\ André Martins de Souza ${ }^{1 *}$; Sandra Galbeiro ${ }^{6}$; Jorge Luís Favaro ${ }^{7}$
}

\section{Highlights:}

The stand with the best proportion of green leaf and higher digestibility was obtained with 525 plants per square meter. The first cutting season provided a higher leaf/stem ratio, greater digestibility of green leaves and stems because it was a young plant.

The cutting of ryegrass in a vegetative stage besides providing the harvest of a plant of high quality, does not reduce the production of dry matter by area when comparing with the cut realized in full vegetative stage.

\begin{abstract}
The Brazilian livestock activity is undergoing constant evolution, and aiming at its maximum efficiency, it is necessary to have available to the animals food in quantity and quality all the year. To this end, the cultivation of winter forage is carried out. The present study aimed to evaluate the productive and qualitative agronomic traits of ryegrass forage. The experiment was a randomized block design in a 3 x 2 factorial arrangement consisting of six treatments, three plant stands (525, 1050 and 2095 plants $\mathrm{m}^{-2}$ ) associated with two successive cutting times (vegetative and full vegetative), and four repetitions. There was no interaction between population stand and cutting times for the variables studied. The stand of 525 plants $\mathrm{m}^{-2}$ had a higher participation of green leaves $(50.52 \%)$, higher digestibility of the whole plant dry matter $\left(84.81 \%\right.$ ) compared to the stands of 1.050 and 2.095 plants $\mathrm{m}^{-2}$, and dry biomass production per unit area equivalent to the others $\left(6087,7243\right.$ and $6989 \mathrm{~kg} \mathrm{ha}^{-1}$, respectively). The first harvest season presented higher participation of green leaves and better leaf/stem ratio, $58.62 \%$ and $3.41 \%$ respectively, as well as higher digestibility of green leaves $(77.26 \%)$ and stem $(80.82 \%)$.
\end{abstract}

Key words: Dry biomass. Haylage. Lolium multiflorum. Plant population.

\footnotetext{
1 Discentes, Pós-Graduação em Produção Agronomia, Universidade Estadual do Centro-Oeste, UNICENTRO, Guarapuava, PR, Brasil. E-mail: andre.dochwat@hotmail.com; andrems92@hotmail.com

2 Prof., Programa de Pós-Graduação, Área de Produção Vegetal e em Ciências Veterinárias, UNICENTRO, Guarapuava, PR, Brasil. E-mail: neumann.mikael@hotmail.com

3 Mestres, Ciências Veterinárias, UNICENTRO, Guarapuava, PR, Brasil. E-mail: edelmirjunior@hotmail.com; bru.ze.venancio@ gmail.com

${ }^{4}$ Eng $^{\mathrm{a}}$ Agr $^{\mathrm{a}}$, Faculdade Campo Real, Guarapuava, PR, Brasil. E-mail: emylli.pe95@gmail.com

5 Discente, Programa de Pós-Graduação em Ciências Veterinárias, UNICENTRO, Guarapuava, PR, Brasil. E-mail: giovannabpontarolo@hotmail.com

6 Prof ${ }^{\mathrm{a}} \mathrm{Dr}^{\mathrm{a}}$, Curso de Zootecnia, Universidade Estadual de Londrina, UEL, Londrina, PR, Brasil. E-mail: sgalbeiro@uel.br

7 Prof., Programa de Pós-Graduação em Ciências Veterinárias, UNICENTRO, Guarapuava, PR, Brasil. E-mail: jorgelfavaro@uol. com.br

* Author for correspondence
} 


\title{
Resumo
}

\begin{abstract}
A atividade pecuária brasileira vem passando por constante evolução, visando sua máxima eficiência, ter disponível para os animais alimento em quantidade e qualidade o ano todo se faz necessário, para isso realiza-se o cultivo de forragens de inverno, o presente trabalho objetivou avaliar as características agronômicas produtivas e qualitativas da forragem do azevém. $\mathrm{O}$ delineamento experimental foi o de blocos ao acaso, num esquema fatorial $3 \times 2$, composto por seis tratamentos, sendo três estandes de plantas $\left(525,1.050\right.$ e 2.095 plantas $\left.\mathrm{m}^{2}\right)$ associado a duas épocas de corte sucessivas (vegetativo e pleno vegetativo) e quatro repetições. Não ocorreu interação entre estande populacional e épocas de corte para as variáveis estudadas. O estande de 525 plantas $\mathrm{m}^{-2}$ apresentou maior participação de folhas verdes $(50,52 \%)$, maior digestibilidade da matéria seca da planta inteira $(84,81 \%)$ em relação aos estandes de 1.050 e 2.095 plantas $\mathrm{m}^{-2}$, e produção de biomassa seca por unidade de área equivalente aos demais $\left(6.087,7.243\right.$ e $6989 \mathrm{~kg} \mathrm{ha}^{-1}$ respectivamente). A primeira época de colheita apresentou maior participação de folhas verdes e melhor relação folha/colmo 58,62 \% e 3,41 \% respectivamente, assim como maior digestibilidade das frações folhas verdes $(77,26 \%)$ e do colmo $(80,82 \%)$.

Palavras-chave: Biomassa seca. Lolium multiflorum. Pré-secado. População de plantas.
\end{abstract}

\section{Introduction}

With the expressive evolution of the farming activity in Brazil in recent years, it is noticeable that the diversification of activities on farmlands is remarkable, once the production areas have multiple functions, such as grain production and animal feeding areas, creating a context where maximum efficiency is required. Considering this premise, the utilization of winter grasses in pastoral systems has great importance in subtropical tempered climate regions, both in grazing-based systems and in forage conservation based systems.

Characteristics associated with the plant stand in ryegrass (Lolium multiflorum) cultivation have been receiving great attention regarding this relation to dry matter (DM) accumulation. Studies evaluate many plant populations, with varying results about the culture productivity. However, the effect of this variable on the nutritive value of the forage have been neglected, especially in studies performed in Brazil.

Alvim and Martins (1986) suggested the utilization of 400 to 550 plants per square meter in the formation of ryegrass pasture. Flaresso, Gross and Almeida (2001), seeking to determine the seeding density for High Vale do Itajaí, Santa Catarina, suggested the use of 400 plants per square meter. Tonetto et al. (2011) used the density of
650 plants per square meter in a study comparing ryegrass genotypes with emphasis on duple deposit culture, dry mass and seed production.

In a recent publication about forage for the croplivestock-forest integration in the country South region, researchers recommend the utilization of 25 - $40 \mathrm{~kg} \mathrm{ha}^{-1}$ ryegrass seeds (Fontaneli, Santos, \& Fontaneli, 2012).

Studies that seek to determine the ideal stand of ryegrass plants usually evaluate the accumulation of dry matter, and do not determine the ideal relationship between ryegrass population and chemical composition and/or the digestibility of the dry matter or the fiber fraction.

Based on this premise, the main goal of this study was to evaluate the productive and qualitative agronomic traits of ryegrass forage in a crop with different population stands associated with two cutting seasons.

\section{Material and Methods}

The experiment was conducted by the Animal Production Center (NUPRAN), belonging to the Agrarian and Environmental Center of MidWest State University (UNICENTRO), located in Guarapuava, State of Paraná, subtropical zone, at the geographic coordinates $25^{\circ} 23^{\prime} 02^{\prime \prime}$ South 
latitude and $51^{\circ} 29$ ' 43 " West longitude, 1,026 meters altitude.

The climate in the region, according to the Köppen classification is $\mathrm{Cfb}$ (Humid Mesothermal Subtropical), with cool summer seasons and moderated winter seasons, without a defined dry season and with severe frosts. The annual rainfall is around $1944 \mathrm{~mm}$, and the average minimum temperature is $12.7^{\circ} \mathrm{C}$, while the average maximum temperature is $23.5^{\circ} \mathrm{C}$ with a relative humidity of $77.9 \%$. Figure 1 illustrates the average rainfall in $\mathrm{mm}$, as well as the maximum and minimum temperature in ${ }^{\circ} \mathrm{C}$ during the experimental period.

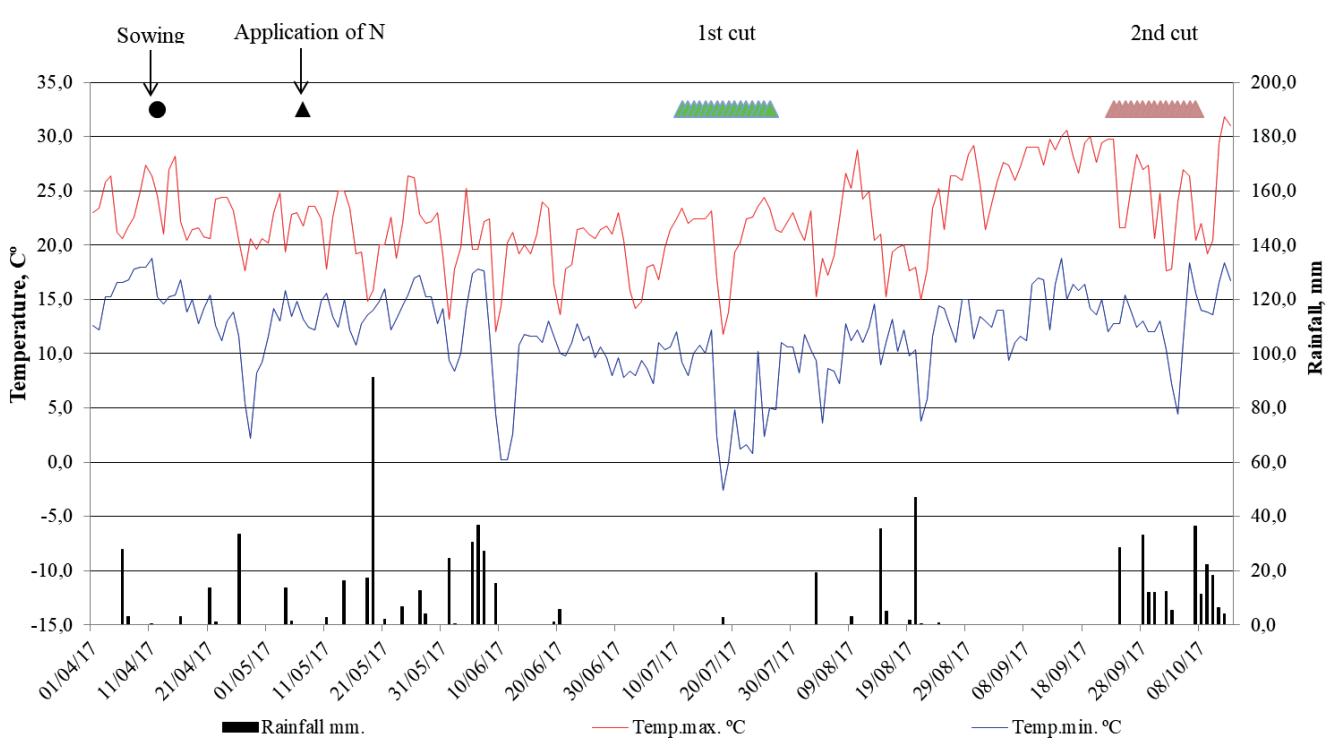

Figure 1. Rainfall $(\mathrm{mm})$, maximum and minimum temperature $\left({ }^{\circ} \mathrm{C}\right)$ during the growing season of the crop.

Experimental station of SIMEPAR/UNICENTRO, Guarapuava, State of Paraná, 2017.

The soil of the experimental area was classified as Typical Dark-Red Oxisol Pott, Müller and Bertelli (2007), and presented the following chemical characteristics ( 0 to 20 centimeters profile): $\mathrm{pH}$ (CaCl2 0.01M): 4.7; P: $1.1 \mathrm{mg} \mathrm{dm}-3$; $\mathrm{K}+: 0.2$ cmolc dm-3; OM: 2.62 g dm-3; Al3+: 0.0 cmolc dm-3; H+ $+\mathrm{A} 13+$ : 5.2 cmolc dm-3; $\mathrm{Ca} 2+: 5.0$ cmolc dm-3; $\mathrm{Mg} 2+: 5.0$ cmolc dm-3 and base saturation (V \%): $67.3 \%$.

Ryegrass (Lolium multiflorum) Winter Star was sown according to the agricultural zoning for the Guarapuava, Paraná region, in no-till system. Sowing was performed with 0.17 meters between rows, in a seeding depth of approximately two centimeters. The experimental area was previously planted with corn for the production of silage and consisted of 102 square meters area, distributed in 12 plots portions of 8.5 square meters each $(1.70 \mathrm{~m} \times 5.00 \mathrm{~m})$, each portion representing an experimental unit (repetition).

The experimental design was the randomized blocks, in a $3 \times 2$ factorial arrangement, composed of six treatments of three plant stands $(525,1050$ and 2095 plants per square meter) associated with two successive cut seasons (vegetative and full vegetative) and four replications. Due to sowing, basal fertilization was performed with $285 \mathrm{~kg} \mathrm{ha}^{-1}$ 08-30-20 (N- $\left.\mathrm{P}_{2} \mathrm{O}_{5}-\mathrm{K}_{2} \mathrm{O}\right)$ fertilizer, according to recommendations of the Fertilizing and Liming Manual for the State of Parana (Moreira et al., 2017). The Topdressing nitrogen fertilization was applied at once with $200 \mathrm{~kg} \mathrm{~N} \mathrm{ha}^{-1}$, as urea, during full profiling phase. 
Weeds were chemically controlled by the use of Glyphosate based herbicides (commercial product Roundup $\mathrm{WG}^{\circledR}: 3.0 \mathrm{~kg} \mathrm{ha}^{-1}$ ) for desiccation of the experimental area, 15 days before seeding, and in the culture management 30 days after planting, with the application of a metsulfuron-methyl based herbicide (commercial product Ally ${ }^{\circledR}: 6.6 \mathrm{~g} \mathrm{ha}^{-1}$ ).

The number of plants in the population was determined 15 days after emergence, by counting their numbers in one square meter. Sequentially, 35 days after emergence, tillers were counted for each treatment, and this was also done by counting within one square meter, which enabled to estimate the number of tillers per plant ${ }^{-1}$.

During crop management, in order to evaluate productive and qualitative characteristics of the forage, two sequential cuts were made, the first cut was made 87 days after the emergence of the plants (vegetative) and the second cut was made 162 days after emergence (full vegetative).

Plants in the useful area of each section $\left(6.8 \mathrm{~m}^{2}\right)$ were cut by hand, 10 centimeters from the ground. The relationship between the weight of the material and the area unit allowed estimating the production of fresh biomass $\left(\mathrm{kg} \mathrm{ha}^{-1}\right)$. A 500 gram sample of freshly harvested material was sent to laboratory for determination of physical composition by segmentation of structural components of forage dehydrated in a forced air oven at $55^{\circ} \mathrm{C}$ to constant weight. The choice for this practice allowed determining the percentage of anatomic structure composition of the plant in stem, green leaves and senescent leaves.

A second sample also weighing 500 grams of each unit was collected and sent to laboratory for determination of dry matter percentage, by drying in a forced air oven $55^{\circ} \mathrm{C}$ to constant weight. The relationship between fresh biomass production and dry matter content in the plants allowed estimating the production of total dry biomass $\left(\mathrm{kg} \mathrm{ha}^{-1}\right)$.

Pre-dried samples of the original material were ground in a Wiley mill, with a 1 millimeter sieve, hence determining the total dry matter in an oven at $105{ }^{\circ} \mathrm{C}$ for four hours, the crude protein (CP) by the micro Kjeldahl method and the mineral matter (MM) by incineration at $550{ }^{\circ} \mathrm{C}$ for four hours according to Association of Official Analytical Chemists International [AOAC] (1995). Neutral detergent fiber (NDF), acid detergent fiber (ADF) and lignin (LIG) were determined according to Silva and Queiroz (2009). From the referred values, the hemicellulose (HEM) percentage was estimated by difference between NDF and ADF and cellulose (CEL) by difference between NDF and LIG. The content of total digestible nutrients (TDN, \%) was obtained via the equation [TDN, $\%=87.84-(0.70$ $\mathrm{x}$ ADF)], as suggested by Bolsen, Ashbell and Weinberg (1996).

Digestibility of forage dry matter and the components of the plant, stem, green leaves and senescent leaves was estimated by in situ technique, using nylon bags measuring $12 \mathrm{~cm} \mathrm{x} 8 \mathrm{~cm}$ and with 40 - $60 \mu \mathrm{m}$ pores, containing 5 grams of dry samples of each material, ground to $1 \mathrm{~mm}$, for posterior rumen incubation (Nocek, 1988). Incubation period used for forage were 1, 6, 12, 24, 36 and 48 hours and 48 hours for stem, green leaves and senescent leaves. For such, two 24-month old calves were used, weighting 650 kilos, with rumen fistula.

Data were subjected to analysis of variance (ANOVA) by F-test at $5 \%$ significance and when the difference was detected, the Tukey test was applied to compare multiple pairs at $5 \%$ significance, using SAS (1993) software. The data referring to the dry matter disappearance rate were analyzed by regression analysis (proc reg) in the statistics program (SAS, 1993).

\section{Results and Discussion}

In general, based on the results of analysis of variance (Table 1), there was no significant interaction between population stands and cutting times for the ryegrass productive and qualitative agronomic parameters. 


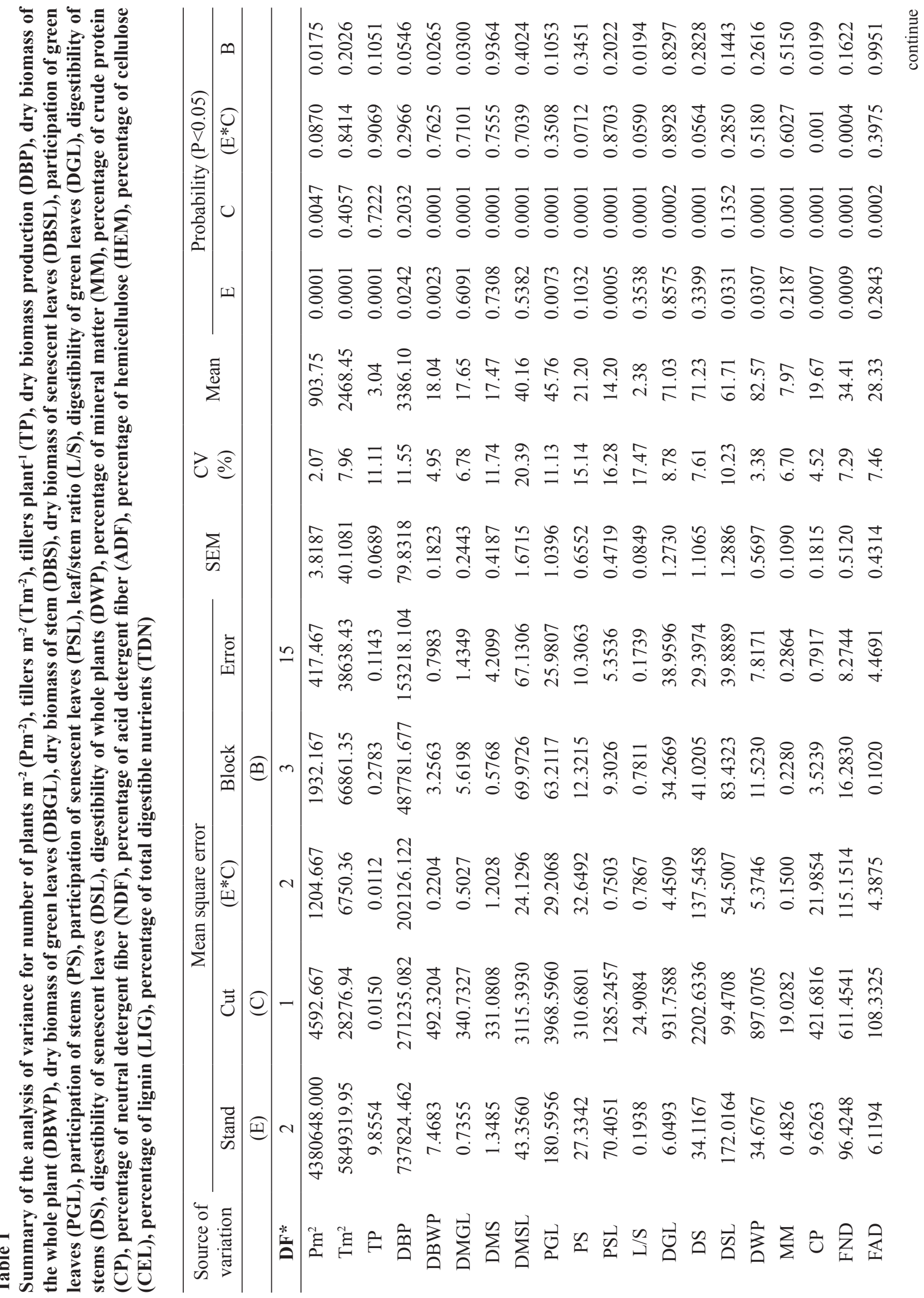




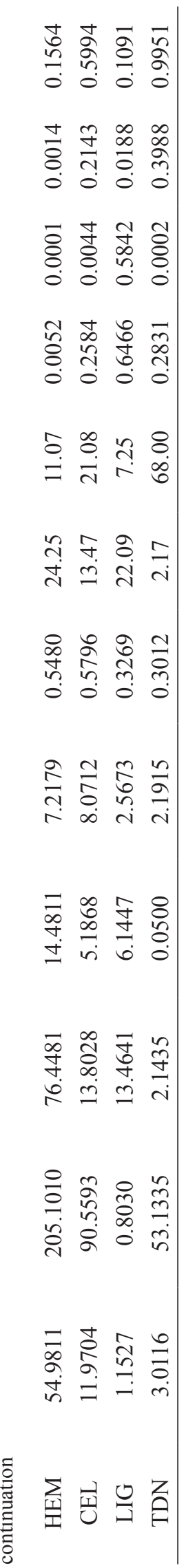

As the plant stands increased, the plant population consequentially grew $(\mathrm{P}<0.05)$, starting with 464 plants $\mathrm{m}^{-2}$ with 525 plants $\mathrm{m}^{-2}$, going to 857 with 1.050 plants $\mathrm{m}^{-2}$ and 1.908 plants $\mathrm{m}^{-2}$ with 2.095 plants $\mathrm{m}^{-2}$. The number of tillers per $\mathrm{m}^{-2}$ followed the same trend, showing a difference of $(\mathrm{P}<0.05)$ starting with 1,548 tillers with 525 plants $\mathrm{m}^{-2}$, to 2,619 with 1,050 plants $\mathrm{m}^{-2}$ and 3,239 tillers $\mathrm{m}^{-2}$ with 2,095 plants $\mathrm{m}^{-2}$. Regarding the number of tillers per plant, no statistical difference could be found $(\mathrm{P}>0.05)$ in stands of 525 and 1,050 plants $\mathrm{m}^{-2}$ with 3.3 and 3.1 tiller plant ${ }^{-1}$, respectively. However, both deffering $(\mathrm{P}<0.05)$ in the stand with 2,095 plants $\mathrm{m}^{-2}$ with 1.6 tiller plant ${ }^{-1}$. Under these conditions, the dry biomass production was not influenced by the plant population.

Flaresso et al. (2001), evaluating ryegrass in densities of 400, 650 and 900 plants $\mathrm{m}^{-2}$, reported values of $6,018,5,784$ and $6,160 \mathrm{~kg} \mathrm{ha}^{-1}$ dry biomass, without significant difference between these values. Kalvelage, Piana and Dallí Agnol (1989) tested densities of 340, 480 and 650 plants $\mathrm{m}^{-2}$ and observed values of 7,218, 7,226 and 7,436 kg $\mathrm{ha}^{-1}$ dry matter, similarly, not observing significant difference. Lemaire and Agnusdei (1999) inferred that the increase in biomass production occurs only when the supply of carbon and nitrogen exceeds the growth demand, so the plant increases the number of active meristems, which increases the tiller density and maintains the continuous growth of the leaves.

All the parameters in Table 2 showed a significant difference $(\mathrm{P}<0.05)$ in the number of plants $\mathrm{m}^{-2}$, being superior in the first cut $(1,001$ against 973 plants $\mathrm{m}^{-2}$ ) compared to the second cut. A. F. Pedroso et al. (2010) analyzed three successive cuts in ryegrass, and found no significant difference between them, reaching values of 2,102; 1,983 and 2,203 $\mathrm{kg}$ dry biomass $\mathrm{ha}^{-1}$ in each cut. On the other hand, Oliveira et al. (2009) found a higher dry biomass production $\mathrm{kg} \mathrm{ha}^{-1}$ in the second cut of ryegrass with an average productivity of $2,514 \mathrm{~kg}$ dry biomass $\mathrm{ha}^{-1}$. 
Table 2

Mean values for the number of plants $\mathrm{m}^{2-1}$, tillers $\mathrm{m}^{2-1}$, tillers plant ${ }^{-1}$ and dry biomass production of ryegrass cultivated with three plant stands associated with two cut seasons

\begin{tabular}{|c|c|c|c|}
\hline \multirow{2}{*}{$\begin{array}{l}\text { Plant } \\
\text { stand }\end{array}$} & \multicolumn{2}{|c|}{$\mathrm{Cut}$} & \multirow[t]{2}{*}{ Average/Total } \\
\hline & Vegetative & Full vegetative & \\
\hline & \multicolumn{3}{|c|}{ Plants $\mathrm{m}^{2-1}$} \\
\hline 525 & 520 & 409 & $464 \mathrm{C}$ \\
\hline 1050 & 1.020 & 694 & $857 \mathrm{~B}$ \\
\hline 2095 & 2.001 & 1.816 & $1.908 \mathrm{~A}$ \\
\hline \multirow[t]{2}{*}{ Mean } & $1.180 \mathrm{a}$ & $973 \mathrm{~b}$ & \\
\hline & \multicolumn{3}{|c|}{ Tillers $\mathrm{m}^{2-1}$} \\
\hline 525 & 1.561 & 1.535 & $1.548 \mathrm{C}$ \\
\hline 1050 & 2.686 & 2.551 & $2.619 \mathrm{~B}$ \\
\hline 2095 & 3.261 & 3.216 & $3.239 \mathrm{~A}$ \\
\hline \multirow[t]{2}{*}{ Mean } & $2.503 \mathrm{a}$ & $2.434 \mathrm{a}$ & \\
\hline & \multicolumn{3}{|c|}{ Tillers plant ${ }^{-1}$} \\
\hline 525 & 3.0 & 3.7 & $3.3 \mathrm{~A}$ \\
\hline 1050 & 2.6 & 3.6 & $3.1 \mathrm{~A}$ \\
\hline 2095 & 1.6 & 1.7 & $1.6 \mathrm{~B}$ \\
\hline \multirow[t]{2}{*}{ Mean } & $2.4 \mathrm{a}$ & $3.0 \mathrm{a}$ & \\
\hline & \multicolumn{3}{|c|}{ Dry biomass production, $\mathrm{kg} \mathrm{ha}^{-1}$} \\
\hline 525 & 2.768 & 3.320 & $6.087 \mathrm{~A}$ \\
\hline 1050 & 3.540 & 3.703 & $7.243 \mathrm{~A}$ \\
\hline 2095 & 3.533 & 3.456 & $6.989 \mathrm{~A}$ \\
\hline Mean & $3.280 \mathrm{a}$ & $3.493 \mathrm{a}$ & \\
\hline
\end{tabular}

Mean values, followed by different upper cases in the same column, in the comparison between plant stands are significantly different by Tukey's test at $5 \%$.

Mean values, followed by different lower cases in the same row, in the comparison between cut seasons are significantly different by Tukey's test at $5 \%$.

$\mathrm{m}^{2}$ : square meter.

It is suggested that the reduction of plants that occurred in the second cut compared to the first was the period with little rainfall, which may also have influenced the production, since the increase found by Oliveira et al. (2009) is the effect of the higher number of tillers emerged when the plant is cut, a behavior that increases dry biomass production (Pellegrini et al., 2010).

Data in table 3 indicate that the stand of plants influenced the percentage of dry biomass of the whole plant, given that stands with 525 and 1,050 plants $\mathrm{m}^{-2}$ exhibited similar values $(\mathrm{P}>0.05)$ of $174.7 \mathrm{~g} \mathrm{~kg}^{-1}$ and $175.1 \mathrm{~g} \mathrm{~kg}^{-1}$, respectively. On the other hand, they were both inferior $(\mathrm{P}<0.05)$ to 2,095 plants $\mathrm{m}^{-2}$ with $191.6 \mathrm{~g} \mathrm{~kg}^{-1}$. The amount of dry matter in green leaves, stem and senescent leaves did not present difference $(\mathrm{P}<0.05)$ between the plant stands. 
Table 3

Amount of dry mass in the whole plant, green leaves, stem and senescent leaves of ryegrass cultivated in three plant stands associated with two cut seasons

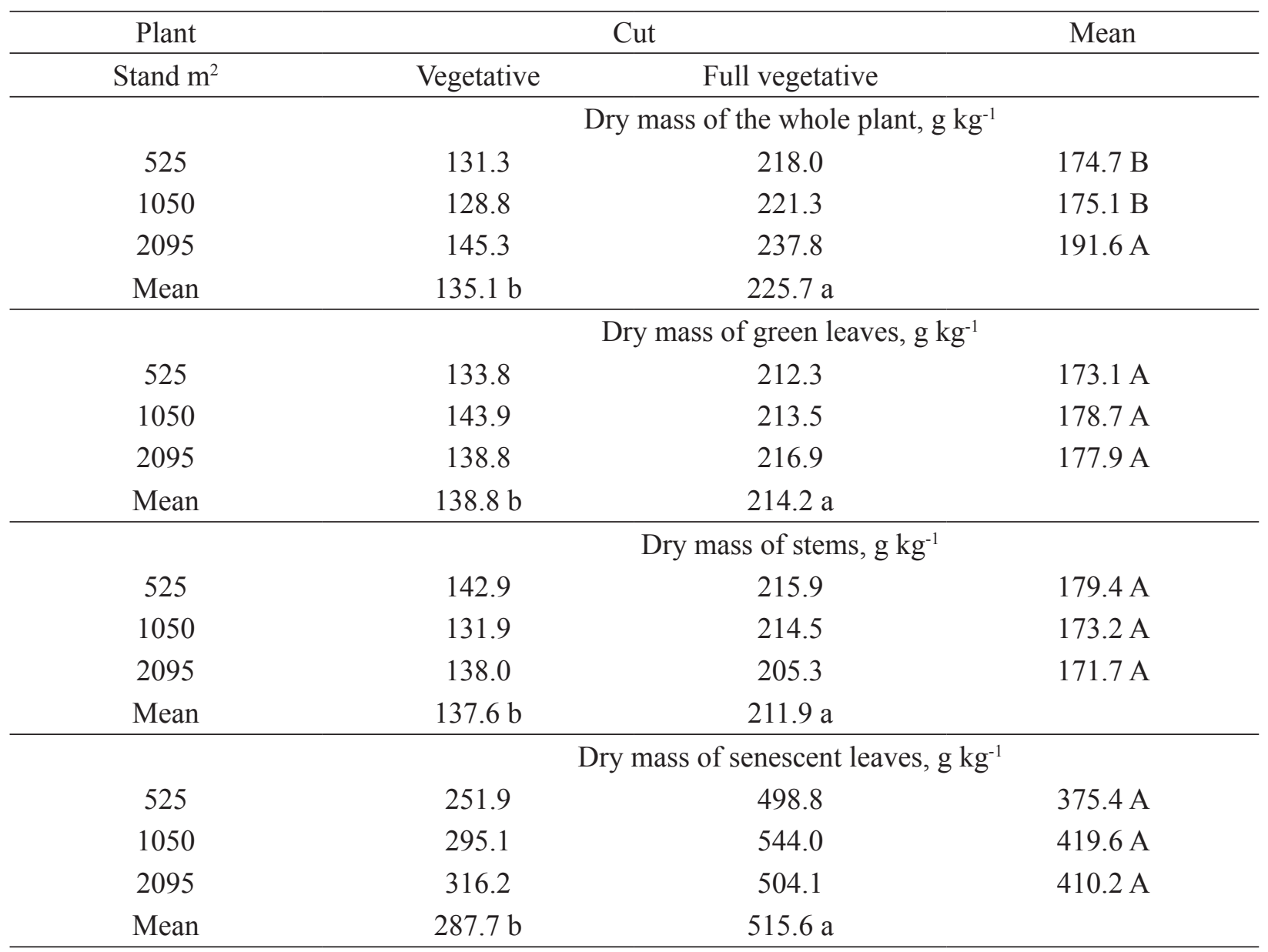

Mean values, followed by different upper cases in the same column, in the comparison between plant stands are significantly different by Tukey's test at $5 \%$.

Mean values, followed by different lower cases in the same row, in the comparison between cut seasons are significantly different by Tukey's test at $5 \%$.

Evaluating two successive cuts, all the content of dry biomass increased in the second cut, varying in the whole plant from $135.1 \mathrm{~g} \mathrm{~kg}^{-1}$ to $225.7 \mathrm{~g}$ $\mathrm{kg}^{-1}$, in green leaves from $138.8 \mathrm{~g} \mathrm{~kg}^{-1}$ to $214.2 \mathrm{~g}$ $\mathrm{kg}^{-1}$, in stem from $137.6 \mathrm{~g} \mathrm{~kg}^{-1}$ to $211.9 \mathrm{~g} \mathrm{~kg}^{-1}$ and in senescent leaves from 287.7 to $515.6 \mathrm{~g} \mathrm{~kg}^{-1}$, compared to the first cut.

When younger, the plant presents a high amount of water, and, as it grows older, the percentage becomes lower as the amount of dry matter increases. According to Benincasa (2003), as the intervals between cuts are extended, the dry matter percentage tends to raise. The little rainfall was another important factor for the variation in the amount of dry matter after the first cut (Figure 1). Fontaneli et al. (2012) stated that ryegrass presents superficial roots between 5 and 15 centimeters, being susceptible to dry periods, leading to a higher plant dehydration. Similar results were obtained by Tonetto et al. (2011), evaluating different periods between cuts of ryegrass fields and also by Neumann et al. (2010), when measuring the vegetative development of forage sorghum. 
The participation of green leaves influenced the plant stand, given that where there were 525 plants $\mathrm{m}^{-2}$ a higher participation was observed, $50.52 \%$, superior to $(\mathrm{P}<0.05) 1,050$ plants $\mathrm{m}^{-2}$ with $41.02 \%$, however, they did not statistically differ from 2.095 plants $\mathrm{m}^{-2}$, which presented $45.75 \%$ in participation of green leaves. For the participation of stems, the stand did not show any influence $(\mathrm{P}>0.05)$. But, the participation of senescent leaves was superior $(\mathrm{P}<0.05)$, with 525 plants $\mathrm{m}^{-2}(19.27 \%)$ compared to the density of 1,050 and 2,095 plants $\mathrm{m}^{-2}$, with $11.06 \%$ and $14.62 \%$, respectively. As to the leaf/ stem ratio, there was no difference $(\mathrm{P}>0.05)$ between the plant stands.

In studies by Fioreli, Segabinazzi, Stanqueviski, Schimtz and Molineti (2012), working with different ryegrass fields subjected to cut at the vegetative stage with 900 plants $\mathrm{m}^{-2}$, values superiors to the one in the present experiment were found, presenting 85.2 $\%$ leaves and $11.8 \%$ stem. According to Rocha et al. (2007a), the proportional quantification of plant components is important for the determination of the ideal management, because they can affect the weight gain in grazing grazing animals, as well as the forage for preserved food production, due to the nutritional quality of botanical components. Tonetto et al. (2011), in studies comparing ryegrass farms, using 650 plants $\mathrm{m}^{-2}$, report that the raise of the cuts brought a reduction in the leaf/stem ratio, a result that was not observed in the present study.

Comparing the first and the second cut, (Table $4)$, there was a reduction in the participation of green leaves in the plant structure $(\mathrm{P}<0.05)$, being $58.62 \%$ in the first cut and $32.90 \%$ in the second cut. On the other hand, stem and senescent leaves participation had the opposite behavior, since both raised in the second cut. Stem and senescent leaves participation was $17.60 \%$ and $6.89 \%$ in the first cut and $24.80 \%$ and $21.52 \%$ in the second cut. Also, leaf/stem ratio was smaller $(\mathrm{P}<0.05)$ on the second cut, reducing from 3.41 to 1.37 .

A. F. Pedroso et al. (2010) evaluated the ryegrass production under cutting at the vegetative stage, and verified a leaf and stem participation of 65.04 $\%$ and $30.14 \%$ in the first cut, showing values superior to the ones in the present study. The same authors explain, however, that the participation of leaves was smaller on posterior cuts, while the participation of stems increased.

The lower participation of leaves in the composition of the plant indicates a higher ability to elongate the stem. This is a negative characteristic, because it may result in a lower digestibility and thus, be not accepted by the animal (Tonetto et al., 2011). A high leaf participation is important to increase digestibility of dry matter ingested (Grise et al., 2001).

The plant stand did not influence $(\mathrm{P}>0.05)$ the contents of mineral matter and acid detergent fiber. For the content of crude protein, the stand with 1,050 plants $\mathrm{m}^{-2}$ presented higher values $(\mathrm{P}<0.05)$ $(20.76 \%)$ compared to 2,095 plants $\mathrm{m}^{-2}(18.57 \%)$, and intermediate values with 525 plants $\mathrm{m}^{-2}$ with $19.69 \%$. Using 1,050 plants $\mathrm{m}^{-2}$, neutral detergent fiber presented a higher value $(\mathrm{P}<0.05)$ with 43.28 $\%$, compared to 525 and 2,095 plants $\mathrm{m}^{-2}$, with $36.56 \%$ and $38.40 \%$, respectively. 


\section{Table 4}

Participation of green leaves, stems and senescent leaves in the physical composition of the plant and the leaf/ stem ratio on ryegrass cultivated in three plant stands associated with two cut seasons

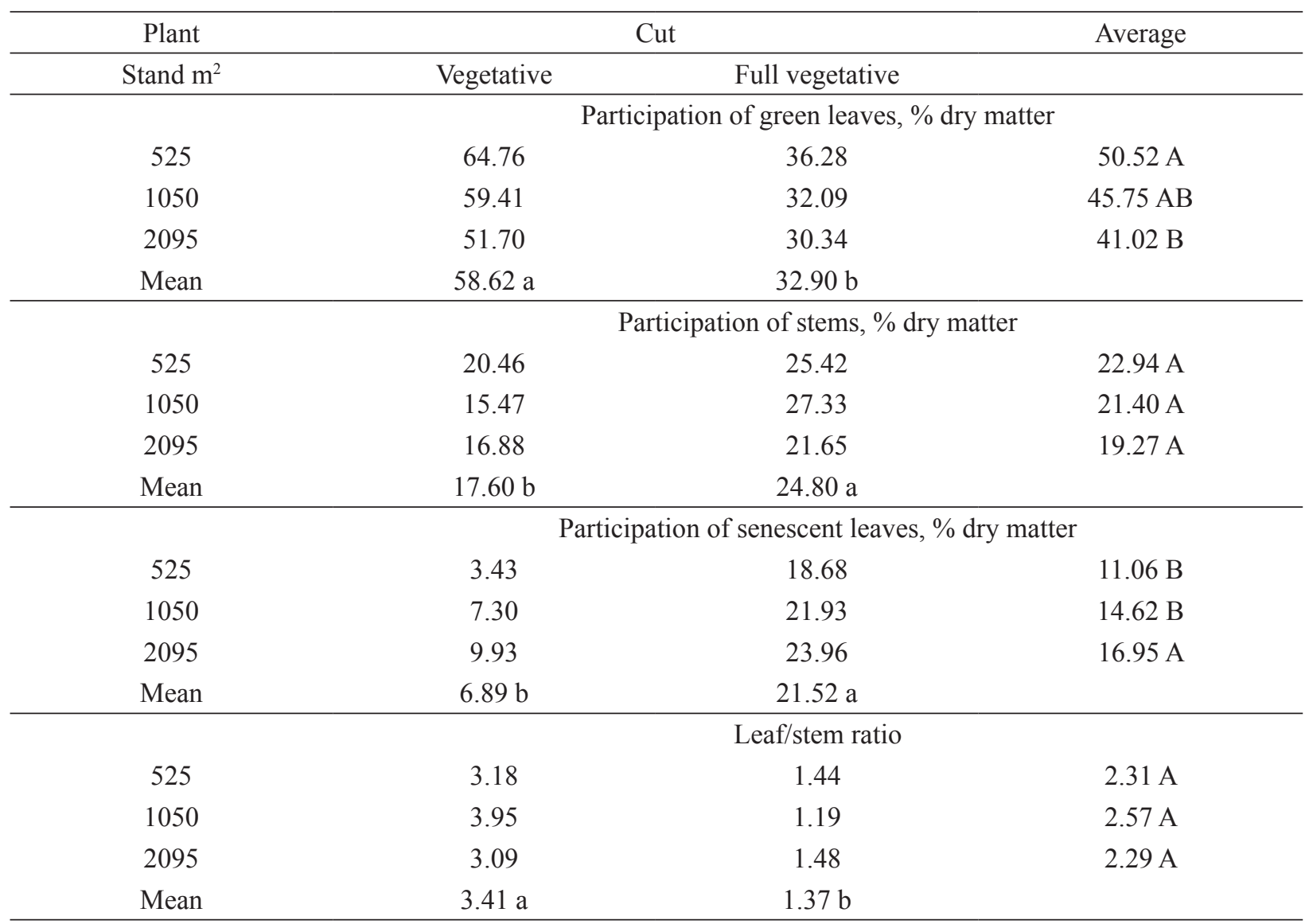

Mean values, followed by different upper cases in the same column, in the comparison between plant stands are significantly different by Tukey's test at $5 \%$.

Mean values, followed by different lower cases in the same row, in the comparison between cut seasons are significantly different by Tukey's test at $5 \%$.

Staine et al. (2011), with 600, 900 and 1,500 plants $\mathrm{m}^{-2}$, reported the amount of $6.52 \% ; 7.01 \%$ and $6.84 \%$ for mineral matter and $21.05 \% ; 20.14$ $\%$ and $18.09 \%$ for crude protein. The same authors also report that when the plant population is high the competition for nutrients also increases, especially nitrogen, a fact that explains the protein reduction in the higher population.

Comparing the cuts, (Table 5), regardless of the plant stands, the mineral matter and crude protein content were reduced $(\mathrm{P}<0.05)$ from the first to the second cut, from $8.87 \%$ to $7.09 \%$ and from 23.86 $\%$ to $15.48 \%$, respectively.
Crude protein contents are higher at the beginning of the vegetative stage, and reduce as they advance in age, resulting in what Rocha et al. (2007a) and C. E. S. Pedroso, Medeiros and Silva (2004) found out. The authors verified higher amounts of crude protein in ryegrass at the vegetative stage (about $23.7 \%$ ), which diminished as the plants started to bloom.

Determining the amount of neutral detergent fiber and acid detergent fiber is extremely important, mainly because of their relationship with the intake of dry matter and forage digestibility (Van Soest, 1994). Table 5 shows that the contents of neutral 
and acid detergent fibers increased $(\mathrm{P}<0.05)$ from

the first to the second cut, from $34.36 \%$ to $44.46 \%$

and from $26.21 \%$ to $30.46 \%$, respectively.

Table 5

Percentage of mineral matter, crude protein, neutral detergent fiber, acid detergent fiber, hemicellulose, cellulose, lignin and total digestible nutrients of ryegrass cultivated in three plant stands associated with two cut seasons

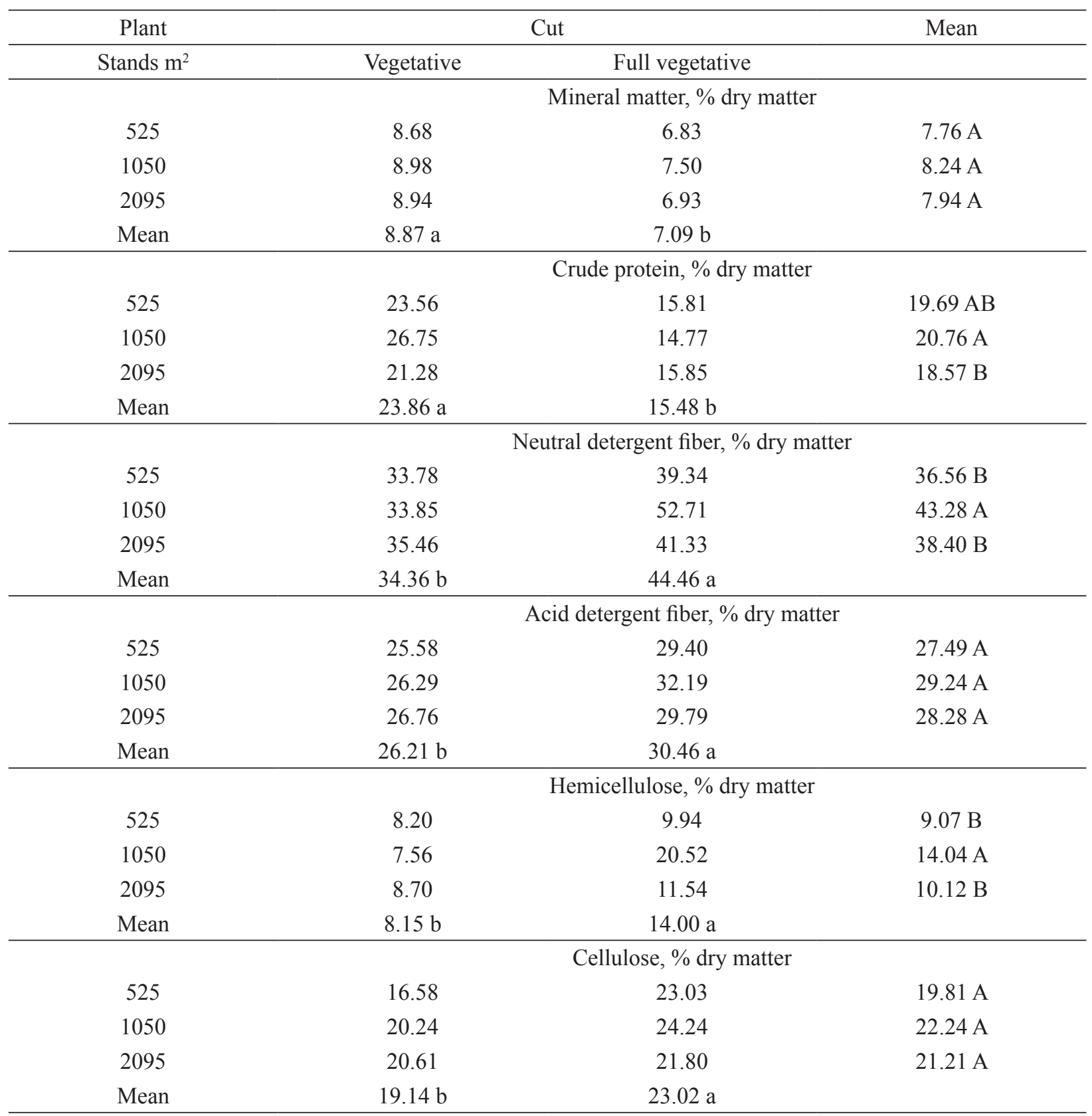




\begin{tabular}{cccc}
\hline & \multicolumn{3}{c}{ Lignin, \% dry matter } \\
525 & 9.00 & 6.37 & $7.69 \mathrm{~A}$ \\
1050 & 6.05 & 7.94 & $7.00 \mathrm{~A}$ \\
2095 & 6.15 & 7.99 & $7.07 \mathrm{~A}$ \\
Mean & $7.07 \mathrm{a}$ & $7.43 \mathrm{a}$ & \\
525 & 69.94 & Total digestible nutrients, \% & $68.60 \mathrm{~A}$ \\
1050 & 69.44 & 67.26 & $67.38 \mathrm{~A}$ \\
2095 & 69.11 & 65.31 & $68.05 \mathrm{~A}$ \\
Mean & $69.50 \mathrm{a}$ & 66.99 & \\
\hline
\end{tabular}

Mean values, followed by different upper cases in the same column, in the comparison between plant stands are significantly different by Tukey's test at $5 \%$.

Mean values, followed by different lower cases in the same row, in the comparison between cut seasons are significantly different by Tukey's test at $5 \%$.

Tonetto et al. (2011), comparing ryegrass farms, observed that the rise in the number of cuts leads to a higher dry matter accumulation. On the other hand, there is a reduction in the percentage of crude protein, which explains the results obtained.

Silveira (2015) worked with 650 plants $\mathrm{m}^{-2}$ with two cuts at the vegetative stage and concluded that the contents of acid detergent fiber were $22.48 \%$ in the first cut and $23.06 \%$ in the second cut. Those values are inferior to the ones observed in this study, but they suggest the same behavior, for showing a raise on the structural fiber fraction. For the contents of neutral detergent fiber, the same author found results that differ from those of the present study, with numbers of $51.15 \%$ in the first cut and 53.21 $\%$ in the second cut.

The amount of hemicellulose was influenced by the plant stands; in a 1,050 plants $\mathrm{m}^{-2}$ stand a higher value was observed, with $14.04 \%$, differing $(\mathrm{P}<0.05)$ from the stands with 525 and 2,095 plants $\mathrm{m}^{-2}$ with $9.07 \%$ and $10.12 \%$ hemicellulose, showing similar results to each other. For cellulose, lignin and digestible nutrients, there was no influence of the plant stands $(\mathrm{P}>0.05)$.
Comparing the two cuts, in Table 5, the percentages of hemicellulose and cellulose increased $(\mathrm{P}<0.05)$ in the second cut, in a way that hemicellulose increased from $8.15 \%$ to $14.00 \%$ and cellulose from $19.14 \%$ to $23.02 \%$, respectively. The content of lignin was stable $(\mathrm{P}>0.05)$ in both cuts, but the content of total digestible nutrients decreased $(\mathrm{P}<0.05)$ in the second cut, from 69.50 $\%$ to $66.52 \%$. It is suggested that the results above reflect the lower participation of green leaves, lower leaf/stem ratio and higher participation of stems and senescent leaves in plants in the second cut (Table 4), structures having a high participation of fiber compounds.

Digestibility of dry matter of the whole plant (Table 6) suffered influence from the plant stands. With 525 plants, the higher value was observed, $84.81 \%$, differing $(\mathrm{P}<0.05)$ from 1,050 plants $\mathrm{m}^{-2}$ with $80.69 \%$ and both differing from 2,095 plants $\mathrm{m}^{-2}$ with $82.70 \%$. Staine et al. (2011) used 600, 900 and 1,500 ryegrass plants $\mathrm{m}^{2}$, reported average in vitro digestibility of $80.01 \%, 81.02 \%$ and $79.41 \%$ respectively, and found no influence of the plant population on the plant digestibility. 
Table 6

In situ digestibility of the whole plant and structural components of the forage (48 hours incubation) of ryegrass cultivated in three plant stands associated with two cut seasons

\begin{tabular}{|c|c|c|c|}
\hline \multirow{2}{*}{$\begin{array}{c}\text { Plant } \\
\text { Stands } \mathrm{m}^{2}\end{array}$} & \multicolumn{2}{|c|}{ Cut } & Mean \\
\hline & $1^{\mathrm{o}}$ & $2^{\circ}$ & \\
\hline & \multicolumn{3}{|c|}{ In situ digestibility of the whole plant, $\%$} \\
\hline 525 & 91.50 & & $84.81 \mathrm{~A}$ \\
\hline 1050 & 85.87 & & $80.69 \mathrm{~B}$ \\
\hline 2095 & 88.68 & & $82.70 \mathrm{AB}$ \\
\hline \multirow[t]{2}{*}{ Mean } & $88.69 \mathrm{a}$ & \multicolumn{2}{|c|}{$76.46 \mathrm{~b}$} \\
\hline & \multicolumn{3}{|c|}{ In situ digestibility of green leaves, $\%$} \\
\hline 525 & 76.53 & 64.48 & $70.51 \mathrm{~A}$ \\
\hline 1050 & 77.64 & 66.42 & $72.03 \mathrm{~A}$ \\
\hline 2095 & 77.61 & 63.49 & $70.55 \mathrm{~A}$ \\
\hline \multirow[t]{2}{*}{ Mean } & $77.26 \mathrm{a}$ & $64.80 \mathrm{~b}$ & \\
\hline & \multicolumn{3}{|c|}{ In situ digestibility of stems, $\%$} \\
\hline 525 & 76.56 & 63.98 & $70.27 \mathrm{~A}$ \\
\hline 1050 & 84.07 & 55.59 & $69.83 \mathrm{~A}$ \\
\hline 2095 & 81.82 & 65.39 & $73.61 \mathrm{~A}$ \\
\hline \multirow[t]{2}{*}{ Mean } & $80.82 \mathrm{a}$ & $61.65 \mathrm{~b}$ & \\
\hline & \multicolumn{3}{|c|}{ In situ digestibility of senescent leaves, $\%$} \\
\hline 525 & 56.71 & 63.01 & $59.86 \mathrm{AB}$ \\
\hline 1050 & 63.09 & 70.90 & $67.00 \mathrm{~A}$ \\
\hline 2095 & 59.25 & 57.35 & $58.30 \mathrm{~B}$ \\
\hline Mean & $59.68 \mathrm{a}$ & $63.75 \mathrm{a}$ & \\
\hline
\end{tabular}

Mean values, followed by different upper cases in the same column, in the comparison between plant stands are significantly different by Tukey's test at $5 \%$.

Mean values, followed by different lower cases in the same row, in the comparison between cut seasons are significantly different by Tukey's test at $5 \%$.

Moreira, Salles and Sobreira (2006) evaluated ryegrass digestibility and reported that with increasing participation of leaves in the physical composition of the plant, the contents of crude protein and digestibility tend to grow. Such affirmation explains the fact that the largest populations of the present study showed smaller coefficients for digestibility and crude protein levels.

For digestibility between the cuts, the first had superior $(\mathrm{P}<0.05)$ results, with $88.69 \%$, while the second cut presented a level of $76.46 \%$ digestibility of the whole plant.

It is possible to observe that the plant stand did not influence the digestibility of green leaves and stems, but it was important for senescent leaves. When presenting 1,050 plants $\mathrm{m}^{-2}$ digestibility reached $67.00 \%$, significantly differing from the stand with 2,095 plants $\mathrm{m}^{-2}$, with $58.30 \%$. Still, in the stand with 525 plants $\mathrm{m}^{-2}$, digestibility of senescent leaves did not differ, with $59.86 \%$.

Still in Table 6, when comparing digestibility of green leaves and stems, it reduced noticeably in the second cut. Green leaves presented higher $(\mathrm{P}<0.05)$ digestibility in the first cut, from $77.26 \%$ to $64.80 \%$ in the second cut. As for stems, values reduced from $80.82 \%$ in the first cut to $61.65 \%$ in the second cut. Digestibility of senescent leaves showed an opposite behavior, from $59.68 \%$ in the first cut $(\mathrm{P}<0.05)$ to $63.75 \%$ in the second cut. 
On the reduction of digestibility of green leaves and stems, according to Benincasa (2003), the chronological factor has a strong impact. As the plants mature, there is thickening and lignification of the wall and reduction of the cell content, decreasing the leaf/stem ratio, elevating the fiber content. Consequently, the concentration of digestible components decreases drastically.

A. F. Pedroso et al. (2010), evaluating ryegrass subjected to successive cuts and detected no difference for the digestibility of green leaves and stem at the vegetative stage. The difference was only found when the cut was performed at the full vegetative stage.

It is possible to observe that the first cut presented the highest content of total soluble nutrients, value represented by the curve intercept, which shows that the stand with 525 plants $\mathrm{m}^{-2}$ had the greatest amounts, with $47.44 \%$, followed by stands with
1,050 and 2,095 plants $\mathrm{m}^{-2}$, with $45.88 \%$ and 43.05 $\%$, respectively, in the first cut. (Figure 2).

Rocha et al. (2007b) reported that the chemical quality of the forage can be explained by the reduction in the proportion of leaves, increase in stems and dead material and the lignification of cell walls through the development of the forage plant cycle. Such affirmation confirms the results of the present study, since that, in the second cut, the proportion of leaves decreased, while the proportion of stems increased (Table 4). Also, chemical parameters and digestibility of the material diminished in the second cut (Tables 5 and 6).

In general lines, ruminal disappearance rate of dry matter of plants obtained in the present study can be classified as being of good quality, according to Leng (1990) scale, which reports that forage classified as low quality present values inferior to $55 \%$ (Figure 2).

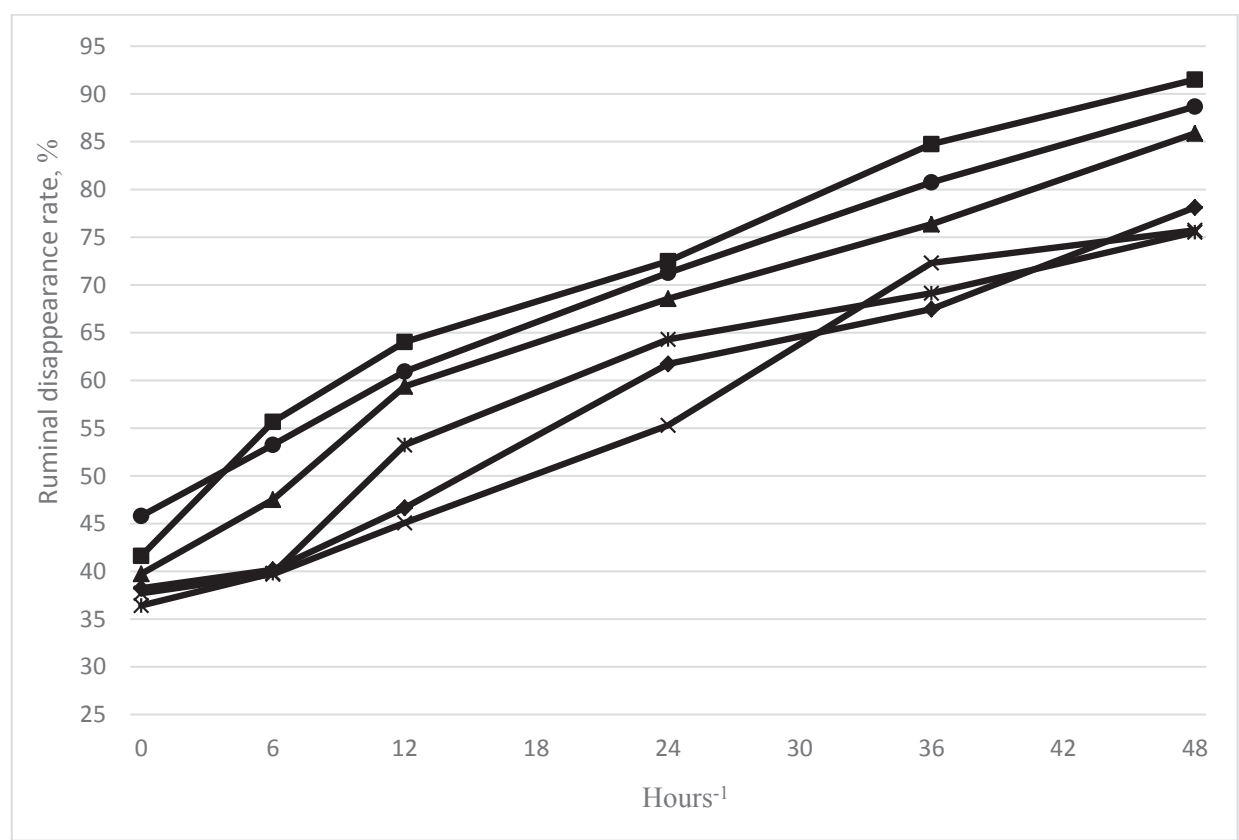

Figure 2. Ruminal disappearance rate of ryegrass dry matter grown in plant stands associated with two cut seasons.

- RDTDM 525 plants $\mathrm{m}^{2}$ 1st cut: $47.4472+0.9870 \mathrm{H}\left(\mathrm{CV}: 9.87 \%\right.$; $\mathrm{R}^{2}$ : 0.8664; $\left.\mathrm{P}=0.0001\right)$ where

$\mathrm{H}$ represents incubation time varying from 0 to 48 hours.

- RDTDM 1050 plants $\mathrm{m}^{2}$ 1st cut: $43.0505+0.9377 \mathrm{H}\left(\mathrm{CV}: 11.27 \% ; \mathrm{R}^{2}: 0.8414 ; \mathrm{P}=0.0001\right)$

A RDTDM 2095 plants $\mathrm{m}^{2} 1$ st cut: $45.8884+0.8924 \mathrm{H}\left(\mathrm{CV}: 5.49 \% ; \mathrm{R}^{2}: 0.9473 ; \mathrm{P}=0.0001\right)$

- RDTDM 525 plants $\mathrm{m}^{2}$ 2nd cut: $40.7543+0.7768 \mathrm{H}$ (CV: $\left.10.92 \% ; \mathrm{R}^{2}: 0.8243 ; \mathrm{P}=0.0001\right)$

* RDTDM 1050 plants $\mathrm{m}^{2}$ 2nd cut: $38.4002+0.9058 \mathrm{H}\left(\mathrm{CV}: 9.10 \% ; \mathrm{R}^{2}: 0.9007 ; \mathrm{P}=0.0001\right)$

x RDTDM 2095 plants $\mathrm{m}^{2}$ 2nd cut: $35.4606+0.8900 \mathrm{H}\left(\mathrm{CV}: 7.93 \% \mathrm{R}^{2}: 0.9282 ; \mathrm{P}=0.0001\right)$

* Ruminal desappearence rate for Hours. 


\section{Conclusion}

The utilization of 525 plants $\mathrm{m}^{-2}$ in ryegrass cultivation resulted in a higher participation of green leaves in the physical composition of the plant, and a better in situ digestibility of dry matter of the whole plant, without causing a reduction in dry biomass production for area.

The first ryegrass harvest season determined a greater participation of green leaves and a higher leaf/stem ratio, as well as an increase in digestibility of green leaves and stems.

\section{References}

Alvim, M. J., \& Martins, C. E. (1986). Efeito da densidade de semeadura sobre a produção de matéria seca da aveia e do azevém, em cultivos puros ou consorciados. Revista Brasileira de Zootecnia, 15(4), 285-296.

Association of Official Analytical Chemists International (1995). Official methods of analysis. Arlington: AOAC.

Benincasa, M. M. P. (2003). Análise de crescimento de plantas (noções básicas). Jaboticabal: Funep.

Bolsen, K. K., Ashbell, G., \& Weinberg, Z. G. (1996). Silage fermentation and silage additives-Review. Asian-Australasian Journal of Animal Sciences, 9(5), 483-493. doi: 10.5713/ajas.1996.483

Fioreli, A. B., Segabinazzi, L. R., Stanqueviski, F., Schimtz, G. R., \& Molineti, M. L. (2012). Produção de forragem dos cultivares de Azevém no Sudoeste do Paraná. Anais do Congresso de Ciência e Técnologia da UTFPR, Curitiba, PR, Brasil, 2.

Flaresso, J. A., Gross, C. D., \& Almeida, E. X. (2001). Época e densidade de semeadura de aveia preta (Avena strigosa Schreb.) e azevém (Lolium multiflorum Lam.) no Alto Vale do Itajaí, Santa Catarina. Revista Brasileira de Zootecnia, 30(6), 1969-1974. doi: 10.1590/S1516-35982001000800002

Fontaneli, R. S., Santos, H. P., \& Fontaneli, R. S. (2012). Forrageiras para integração lavoura-pecuáriafloresta na região sul-brasileira. Brasília, DF: EMBRAPA.

Grise, M. M., Cecato, U., Moraes, A., Canto, M. W., Martins, E. N., Pelissari, A., \& Mira, R. T. (2001). Avaliação da composição química e da digestibilidade in vitro da mistura da aveia IAPAR 61 (Avena strigosa Schreb) + ervilha forrageira (Pisum arvense L.) em diferentes alturas sob pastejo. Revista Brasileira de Zootecnia, 30(3), 659-665. doi: 10.1590/S1516-35982001000300008

Kalvelage, H., Piana, Z., \& Dallí Agnol, M. (1989). Densidade de semeadura de azevém anual e aveia preta. Revista Agropecuária Catarinense, 2(1), 2223.

Lemaire, G., \& Agnusdei, M. (1999). Leaf tissue turnover and efficiency of herbage utilization. Anais do International Symposium Grassland Ecophsiology and Grazing Ecology, Curitiba, PR, Brasil.

Leng, R. A. (1990). Factors affecting the utilization of "poor-quality" forages by ruminants particularly under tropical conditions. Nutrition Research Review, 3(3), 277-303. doi: 10.1079 / NRR19900016

Moreira, A. F., Salles, F. G. E., \& Sobreira, G. W. (2006). Composição bromatologicas de gramíneas temperadas. Revista Cientifica, 5(4), 40-58.

Moreira, A., Assmann, A. L., Wagner, A., Jr., Silva Gualberto, A. A., Lemiska, A., Moraes, A.,... Natale, W. (2017). Manual de adubação e calagem para o estado do Paraná. Curitiba, PR: SBCS/NEPAR.

Neumann, M., Restle, J., Souza, A. N. M., Pellegrini, L. G., Zanette, P. M., Nornberg, J. L., \& Sandini, I. E. (2010). Desempenho vegetativo e qualitativo do sorgo forrageiro 60 (sorghum bicolor $\mathrm{x}$ sorghum sudanense) em manejo de cortes. Revista Brasileira de Milho e Sorgo, 9(3), 298-313. doi: 10.18512/19806477/rbms.v9n3p298-313

Nocek, J. E. (1988). In situ and other methods to estimate ruminal protein and energy digestibility. Journal Dairy Science, 71(8), 2051-206. doi: 10.3168/jds. S0022-0302(88)79781-7

Oliveira, R. F., Fontoura, D. A. E., Silva, F. A., Araújo, M. F., Mendes, D., \& Caldeira, F. T. (2009). Rendimento de sementes e forragem de azevém-anual em resposta a doses de nitrogênio e a regimes de colheita. Revista Agropecuária Cientifica, 8(4), 45-59.

Pedroso, A. F., Noiman, D. F., Bertegga, G. T. A., Rosa, S. F., Silveira, F. G., \& Rosário, D. A. G. (2010). Valor nutricional da aveia preta e do azevém submetidos a cortes simulando pastejo cultivados em diferentes doses de nitrogênio. Revista Acta Iguazu, 5(6), 2539.

Pedroso, C. E. S., Medeiros, R. B., \& Silva, E. M. A. (2004). Produção de ovinos em gestação e lactação sob pastejo em diferentes estádios 
fenológicos de azevém anual. Revista Brasileira de Zootecnia, 33(5), 1345-1350. doi: 10.1590/S151635982004000500029

Pellegrini, L. G., Monteiro, A. L. G., Neumann, M., Moraes, A., Pellegrin, A. C. R. S., \& Lustosa, S. B. C. (2010). Produção e qualidade de azevémanual submetido a adubação nitrogenada sob pastejo por cordeiros. Revista Brasileira de Zootecnia, 39(9), 1894-1904. doi: 10.1590/S151635982010000900006

Pott, C. A., Müller, M. M. L., \& Bertelli, P. B. (2007). Adubação verde como alternativa agroecológica para recuperação da fertilidade do solo. Revista Ambiência, 3(2), 51-63.

Rocha, M. G., Pereira, L. E. L. T., Scaravelli, L. F. B., Olivo, C. J., Gnolin, C. A., \& Ziech, M. F. (2007b). Produção e qualidade de forragem da mistura de aveia e azevém sob dois métodos de estabelecimento. Revista Brasileira de Zootecnia, 36(1), 7-15. doi: 10.1590/S1516-35982007000100002

Rocha, M. G., Quadros, F. L. F., Glienke, C. L., Confortin, A. C. C., Costa, V. G., \& Rossi, G. E. (2007a). Avaliação de espécies forrageiras de inverno na depressão central do rio grande do sul. Revista Brasileira de Zootecnia, 36(6), 1990-1999. doi: 10.1590/S1516-35982007000900007
Sas Institute. (1993). SAS/STAT user's Guide: statistics, version 4. ed. North Caroline.

Silva, D. J., \& Queiroz, A. C. (2009). Análise de alimentos, métodos químicos e biológicos. Viçosa: Universidade Federal de Viçosa.

Silveira, A. P. (2015). Valor nutritivo de forrageiras de inverno e produção de silagem pré-secada. Dissertação de mestrado, Universidade Tecnológica Federal do Paraná, Dois Vizinhos, PR, Brasil.

Staine, F. A., Cordeiro, F. A., Pedreira, F. A., Cherlsrton, G. A., Norbertis, G. A., \& Ferreira, A. F. B. (2011). Produção e composição bromatológica do azevém (lolium multiflorum) submetidos a diferentes densidades de semeadura e estádios fenológicos de colheita. Revista de Ciências Agrárias, 9(1), 12-25.

Tonetto, C. J., Muller, L., Medeiros, S. L. P., Manfron, P. A., Bandeira, A. H., Morais, K. P.,... Dourado, D., Neto. (2011). Produção e composição bromatológica de genótipos diploides e tetraplóides de azevém. Zootecnia Tropical, 29(2), 169-178.

Van Soest, P. J. (1994). Nutritional ecology of the ruminant. Ithaca: Cornell University Press. 